\title{
Another Arrow in the Quiver - But at What Cost?
}

\author{
D. SCOTT LIM, M.D., THOMAS R. LLOYD, M.D., and MACDONALD DICK II, M.D. \\ From the C.S. Mott Children's Hospital, University of Michigan, Ann Arbor, MI
}

Gamillscheg et al. report on a single patient who had a large pulmonary arteriovenous malformation with significant right-to-left shunting and a cerebrovascular accident secondary to presumed paradoxic embolism. The accompanying still-frame cineangiogram demonstrates a large arteriovenous malformation with a 10 -mm feeding artery and no obvious narrowing, making it difficult to provide endovascular therapy.

We agree that not only does the Amplatzer occluder work in this instance, it is probably the optimal device for such a situation. It is adaptable to a wide range of vessel sizes, with a $4 \mathrm{~mm}$ to $38 \mathrm{~mm}$ central waist diameter. Its nitinol frame gives the device the plasticity needed to fit into tortuous vessel anatomy. Additionally, the connecting cable allows for multiple repositioning of the device and a safety margin from inadvertent embolization. Others have described such off-label use of the Amplatzer atrial septal occluder in pulmonary arteriovenous malformations ${ }^{1}$ and other lesions. ${ }^{2-4}$

Other types of intravascular devices have also been used to deal with such lesions. The most common device is the Gianturco coil. ${ }^{5}$ While the Dacron-tufted stainless steel coil comes in a wide range of sizes (from the tiny $0.018^{\prime \prime} 2 \mathrm{~mm}$ coil to the large $0.052^{\prime \prime} 20 \mathrm{~mm}$ coil), there is still a higher likelihood of embolization in large feeding vessels without a discrete "choke" point. The Gianturco-Grifka vascular occlusion device has been utilized for embolization of pulmonary arteriovenous malformations, ${ }^{6}$ but given the large diameter of the feeding artery, the largest Gianturco-Grifka device $(9 \mathrm{~mm})$ might be inadequate. Large pulmonary arteri-

Address for reprints: Macdonald Dick II, M.D., University of Michigan Health System, F1310 C.S. Mott Children's Hospital, 1500 E. Medical Center Drive, Ann Arbor, MI 48109-0005. Fax: (313) 936-9470; e-mail: mdick@umich.edu ovenous malformations can also be resected surgically, but such procedures are not without significant morbidity and mortality. 7,8

While intravascular device therapy has been shown to be less expensive than many comparative surgical procedures, ${ }^{9-15}$ one must still keep in mind the economic cost of the device used. Based on an analysis of the pediatric cardiac catheterization laboratory costs at our own institution, a pair of Gianturco coils costs $\$ 52.25$. The largest Gianturco-Grifka vascular occlusion device increases the cost ten-fold to $\$ 658.35$, and the same device the authors of this article utilized costs $\$ 3650$. Another commonly used device is the $17-\mathrm{mm}$ CardioSEAL, which increases the cost factor to more than 100 times the cost of a pair of coils at $\$ 5581$.

So the off-label use of the Amplatzer atrial septal occluder should work quite well to occlude unwanted large vascular structures, but in this era of increasing cost containment the interventionalist would do well to weigh the economics of the therapeutic decision ... or someone else will.

\section{References}

1. Naanaa-Baccar H, Godart F, Francart C, et al. Left monoplegia revealing pulmonary arteriovenous fistual in an adolescent: Occclusion with an Amplatzer occluder. Archives des Maladies du Coeur et des Vaisseaux 2001;94:504-508.

2. Sharaf E, Waight DJ, Hijazi ZM. Simultaneous transcatheter occlusion of two atrial baffle leaks and stent implantation for SVC obstruction in a patient after Mustard repair. Cathet Cardiovasc Interv 2001;54:72-76.

3. Szkutnik M, Bialkowski J, Knapik P. Major intrahepatic venovenous fistula after modified Fontan operation treated by transcatheter implantation of Amplatzer septal occluder. Cardiology in the Young 2001;11:357-60.

4. Schneider DJ, Moore JW. Transcatheter treatment of IVC channel obstruction and baffle leak after Mustard procedure for 
LIM, ET AL.

d-transposition of the great arteries using Amplatzer ASD device and multiple stents. J Invasive Cardiol 2001;13:306-309.

5. Ghani M, Yusuf W, Sdringola S, et al. Percutaneous coil embolization of multiple arteriovenous malformations in left lung causing persistent hypoxia. Circulation 2000;102:E118.

6. Ebeid MR, Braden DS, Gaymes CH, et al. Closure of a large pulmonary arteriovenous malformation using multiple GianturcoGrifka vascular occlusion devices. Catheter Cardiovasc Interv 2000;49:426-429.

7. Opanasenko NS, Radionov BV, Voloshin Ia M, et al. Pulmonary resection of arteriovenous fistula. Klinicheskaia Khirurgiia 2000;Sep(9):14-16.

8. Temes RT, Paramsothy P, Endara SA, et al. Resection of a solitary pulmonary arteriovenous malformation by video-assisted thoracic surgery. J Thorac Cardiovasc Surg 1998;116:878-879.

9. Gray DT, Fyler DC, Walker AM, et al. Clinical outcomes and costs of transcatheter as compared with surgical closure of patent ductus arteriosus. The Patent Ductus Arteriosus Closure Comparative Study Group. New Engl J Med 1993;329:15171523 .

10. Cohen DJ, Breall JA, Ho KK, et al. Economics of elective coronary revascularization. Comparison of costs and charges for conventional angioplasty, directional atherectomy, stenting and bypass surgery. J Am Coll Cardiol 1993;22:10521059.

11. Hawkins JA, Minich LL, Tani LY, et al. Cost and efficacy of surgical ligation versus transcatheter coil occlusion of patent ductus arteriosus. J Thor Cardiovas Surg 1996;112:1634-1638; discussion 1638-1639.

12. Kramer RK, Weber HS, Cyran SE. Transcatheter versus surgical closure of patent ductus arteriosus: a cost comparison and cost model. J Cardiovas Manage 2000;11:19-22.

13. Prieto LR, DeCamillo DM, Konrad DJ, et al. Comparison of cost and clinical outcome between transcatheter coil occlusion and surgical closure of isolated patent ductus arteriosus. Pediatrics 1998;101:1020-1024.

14. Singh TP, Morrow WR, Walters HL, et al. Coil occlusion versus conventional surgical closure of patent ductus arteriosus. Am J Cardiol 1997;79:1283-1285.

15. Weerasooriya HR, Murdock CJ, Harris AH, et al. The costeffectiveness of treatment of supraventricular arrhythmias related to an accessory atrioventricular pathway: Comparison of catheter ablation, surgical division and medical treatment. Aust NZ J Med 1994;24:161-167. 